\title{
PENGUATAN PEMAHAMAN AKUNTANSI DAN PERANCANGAN SISTEM INFORMASI MANAJEMEN PADA UKM BATIK TULIS GIRILOYO DI DESA WISATA WUKIRSARI, IMOGIRI BANTUL
}

\author{
Desi Susilawati ${ }^{1)}$, Putri Rachmawati ${ }^{2)}$ \\ ${ }^{1)}$ Program Vokasi Akuntansi, Universitas Muhammadiyah Yogyakarta \\ ${ }^{2)}$ Program Vokasi Teknik Mesin, Universitas Muhammadiyah Yogyakarta \\ desisusilawati@.umy.ac.id
}

DOI : 10.31604/j.martabe.v1i3.89-100

\begin{abstract}
The partner of this program is Paguyuban Batik Tulis Giriloyo Wukirsari village Imogiri Bantul Yogyakarta. Paguyuban has two problems: recording the transaction manually and did not match with the accounting standard for SMEs (Small and Medium Enterprises). Paguyuban does not have an application as an information management system. Information System is a tool of human in storing, processing, and organizing data. The Sophistication of information systems will accelerate the processing and management of data. Based on the above, this devotion program is empowerment, strengthening understanding and technical capability of accounting process related to preparing financial statement easily and accurately. The developing information systems application that will be used in SMEs (Small and Medium Enterprises) to obtain a report of sale, report of inventory based database Access application effectively and relevance. The model of this devotion was descriptive qualitative which measure target quantity, efficient system quality, and timeliness of preparing a financial statement. Based on questionnaire feedback from participant we got $74 \%$ of participant stated that application implementation was easy. Effectiveness is measured by the timeliness of financial reporting. The result shows that financial reporting can be disclosed on time and improve the quality of it. The results above indicate that the access database applications as information needed by Wukirsari batik group community to improve their performances.
\end{abstract}

Keywords: Effectiveness, management information system, small and medium enterprises, Empowering knowledge of accounting.

\begin{abstract}
Abstrak
Mitra usaha dalam program ini adalah usaha kecil menengah pembuatan batik tulis di Desa Wukirsari, Imogiri, Bantul, Daerah Istimewa Yogyakarta. Permasalahan yang dihadapi oleh Paguyuban Batik Tulis Giriloyo Desa Wisata Wukirsari adalah: pencatatan akuntansi yang masih secara manual dan belum memenuhi standart akuntansi, selain itu Paguyuban juga belum memiliki aplikasi sistem informasi manajemen keuangan.Sistem Informasi merupakan alat bantu manusia dalam menyimpan, mengolah, dan mengorganisasi data. Kecanggihan sistem informasi akan mempercepat proses pengolahan dan pengelolaan data. Berdasarkan permasalahan diatas program ini akan mengadakan pelatihan penguatan pemahaman proses akuntansi dalam rangka kemudahan menyusun laporan keuangan. Selanjutnya merancang suatu


aplikasi sistem informasi manajamen keuangan pada UKM (Usaha Kecil dan Menengah) berupa aplikasi sistem penjualan, sistem manajemen persediaan barang dagangan yang berbasis database access dan pendampingan uji coba aplikasi. Program pengabdian ini menggunakan model deskriptif kuantitatif dengan mengukur kuantitas target, kualitas, efektif, efisien dan ketepatan waktu penyusunan laporan. Berdasarkan kuesioner yang dibagikan kepada paguyuban diperoleh data $74 \%$ pengguna aplikasi menyatakan bahwa pengoperasian aplikasi ini mudah. Pengukuran efektifitas sistem informasi ini adalah laporan keuangan, laporan pendapatan, laporan persediaan barang yang tersaji lebih tepat waktu. Hasil yang dicapai bahwa aplikasi database berbasis access sebagai sistem informasi mampu menyediakan laporan sesuai kebutuhan secara cepat, tepat waktu sehingga meningkatkan kulaitas laporan keuangan. Pengembangan dan penerapan aplikasi ini diharapkan dapat memberikan kontribusi yang besar pada kinerja paguyuban kelompok batik Wukirsari.

\section{Kata kunci:Efektivitas, Sistem Informasi Manajemen, Usaha Kecil Menengah, Pemahaman Akuntansi.}

\section{PENDAHULUAN}

Batik adalah sejenis kerajinan yang memiliki nilai seni tinggi yang telah menjadi bagian terbesar dari budaya Indonesia, berupa kain yang dihias, dilukis, ditulis, dengan tekstur dan corak batik menggunakan tangan, cap,lukis.Seiring waktu, batik yang semakin terkenal membawa desa Wukirsari yang juga dikenal sebagai penghasil dan pengrajin batik tulisnya dikalangan masyarakat luas, mulai terhimpun beberapa pengrajin yang kemudian menjadi peguyuban batik yang terdiri atas 10 kelompok. Paguyuban dibentuk bertujuan sebagai wadah/organisasi untuk mengkoordinasikan seluruh pengrajin batik giriloyo sehingga mampu memberikan pelayanan prima kepada konsumen.

Paguyuban batik sekarang ini dikenal sebagai Desa Wisata Giriloyo, dengan wisata yang ditawarkan; wisata kerajinan, wisata rohani, dan wisata alam. Batik tulis giriloyo semakin terkenal dikalangan masyarakat domestik maupun non domestik. Para konsumen mengunjungi workshop batik tulis untuk belajar membatik, melihat secara langsung proses membatik dan juga membeli batik.Transaski penjualan batik, pembelian batik tulis dari kelompok pengrajin dan pembelian bahan baku semakin banyak. Pengelola paguyuban dituntut untuk melakukan pembukuan atau pencatatan atas transaksi tersebut. Tidak dapat dipungkiri dengan sistem informasi yang juga semakin canggih,, dan berkembangnya pangsa pasar, desa wisata batik wukirsari dituntut untuk mengikuti kemajuan sistem informasi tersebut.

Permasalahan yang dialami oleh kelompok Paguyuban batik tulis giriloyo wukirsari saat ini adalah pencatatan transaski masih menggunakan sistem pembukuan secara sederhana yaitu tulis tangan manual dan masih kuno. Kendala terbesar adalah para pengelola masih minim pengetahuannya tentang akuntansi (pembukuan), dikarenakan pengelola tidak berlatar belakang pendidikan akuntansi sehingga keterampilan dan pemahaman proses akuntansi untuk pencatatan transaksi dan penyusunan 
laporan keuangan dan pengetahuan teknis masih kurang.

Sistem keuangan yang dilakukan oleh mitra adalah sederhana dengan menulis pada buku, pembelian bahan baku dan produksi dicatat secara manual. Pada buku tersebut berisi tentang; tamu yang pernah berkunjung, kain batik motif yang masih tersedia, kain batik motif yang sudah terjual, bahan baku yang masih ada atau sudah habis tidak up to date. seperti ; kain mori, pewarna, malam, canting serta order pembelian tersaji pada gambar 1 . Oleh karena itu, Pengabdi mengusulkan solusi berupa penguatan keterampilan dan pemahaman teksis akuntansi dengan metode pelatihan.
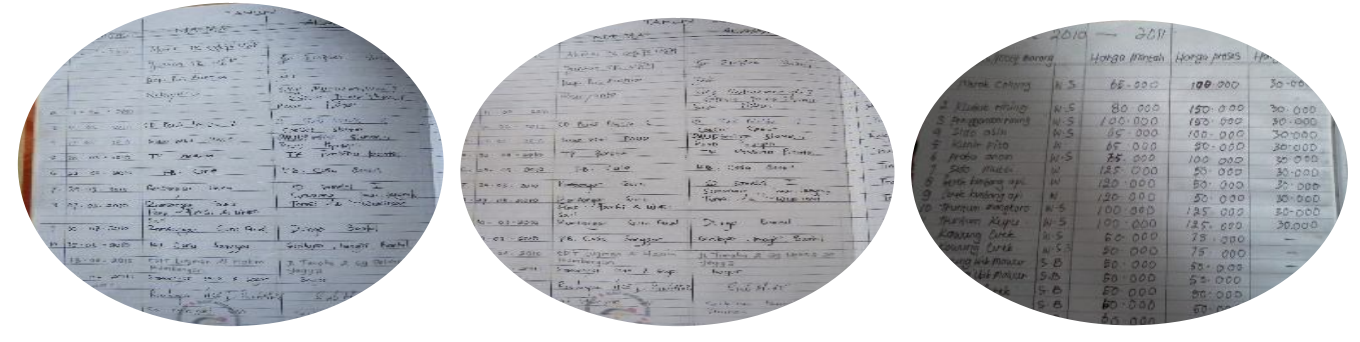

Gambar 1: Contoh pembukuan yang masih manual

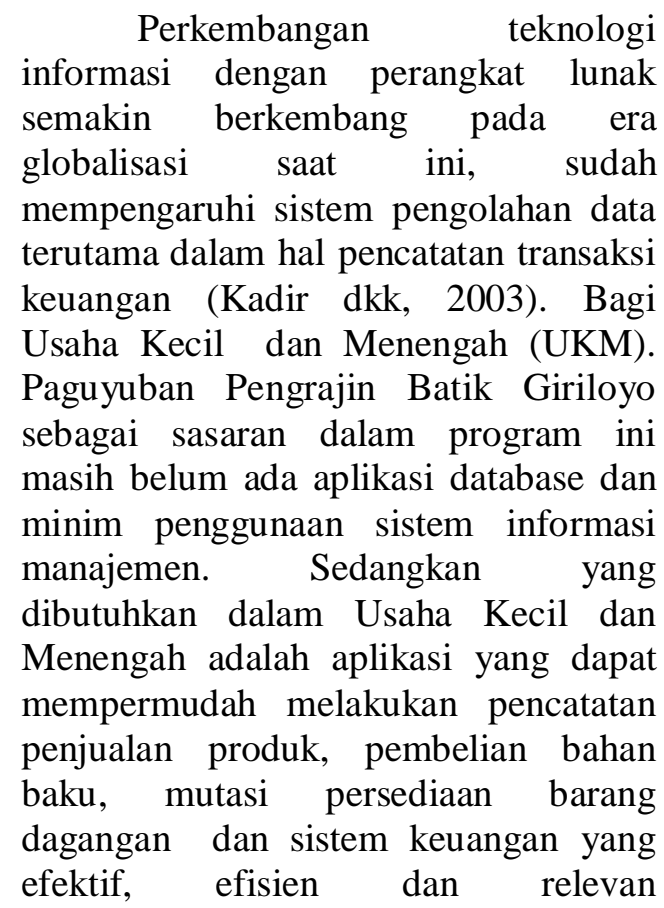

(Rachmawati, 2013). Selanjutnya untuk menjawab tantangan perkembangan teknologi informasi yang semakin pesat, perlu akan adanya perancangan suatu aplikasi sistem informasi manajemen keuangan. Pengabdi akan merancang suatu aplikasi sistem informasi keuangan berbasis database Aceess (Pratikno dkk, 2011).

\begin{abstract}
Sistem informasi manajemen adalah suatu sistem yang bersifat menyeluruh, bertujuan untuk menyajikan informasi yang jauh lebih luas daripada informasi akuntansi yang bersifat historis (Widjajanto, 2011). Teknologi informasi dapat mengatasi keterbatasan untuk mengelola sumber daya yang dimiliki dengan lebih cepat, efisien, dan efektif. Sistem informasi manajemen keuangan merupakan teknologi informasi yang dapat meningkatkan daya saing global suatu usaha, karena dapat meningkatkan efisiensi pada bagian operasional pengusaha batik. Implementasi sistem informasi manajemen keuangan itu sangat terintegrasi dengan sistem manajemen lainnya yang begitu banyak dan membutuhkan biaya, waktu yang harus dikeluarkan oleh pelaku bisnis mulai dari tahap sebelum dan sesudah implementasi (Jogiyanto, 2005).

Sistem manajemen keuangan saat ini yang sifatnya masih sederhana, untuk itu perlu adanya upaya peningkatan kapasitas keterampilan pengelola,fasilitas pendukung aplikasi berbasis database untuk pengelolaan
\end{abstract}


sistem informasi manajemen keuangan..

Berikut disajikan skema sistem keuangan pada paguyuban batik tulis giriloyo Wukirsari.

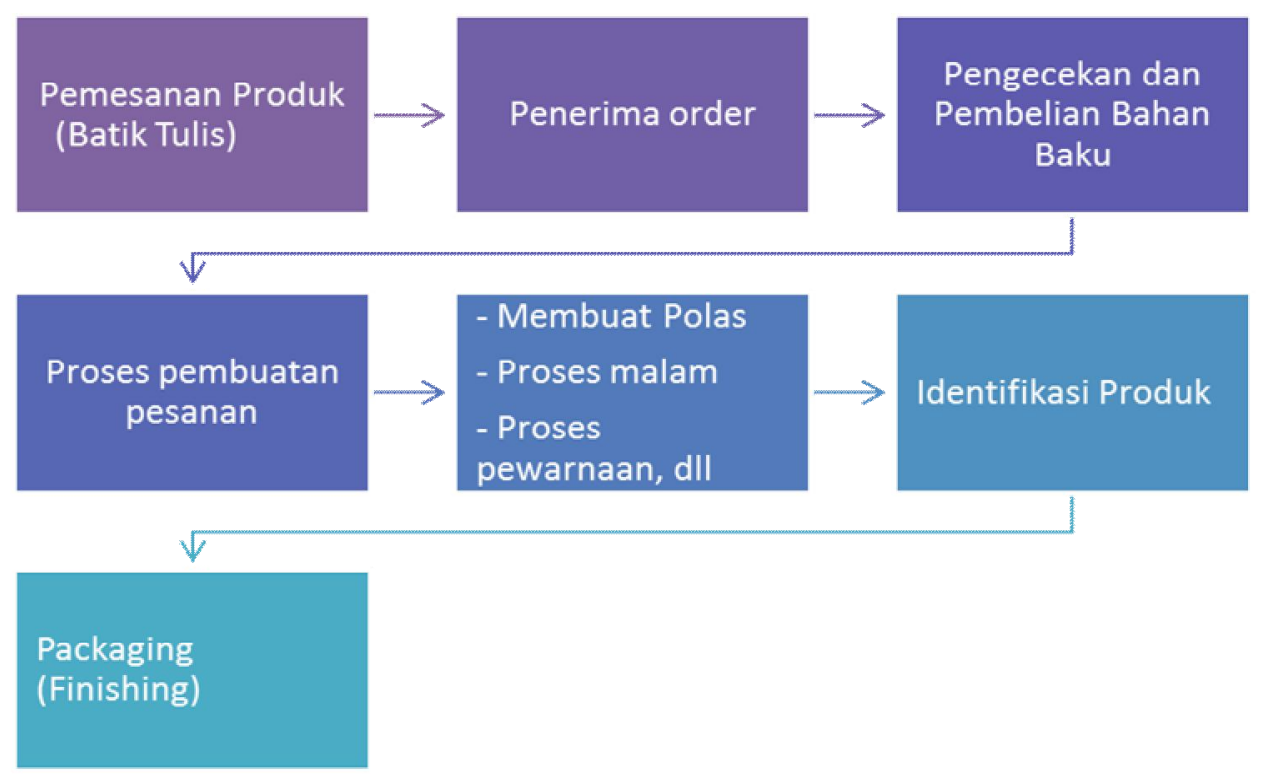

Gambar 2: Skema sistem keuangan pada paguyuban batik tulis wukirsari

Desa wisata giriloyo, terdiri dari 10 kelompok dengan anggota beberapa pembatik, dengan kelompok pembatik yang masih produktif adalah Berkah Lestari, Sri Kuncoro, Giri Canting,
Sumsang batik, Sekar arum, Sekar Kedaton, Sumsing Tumpuk, Sidomukti, Giri Indah, Sukamaju, Sidomulyo dan Bima sakti, berikut hasil produk dari beberapa kelompok pengrajin:

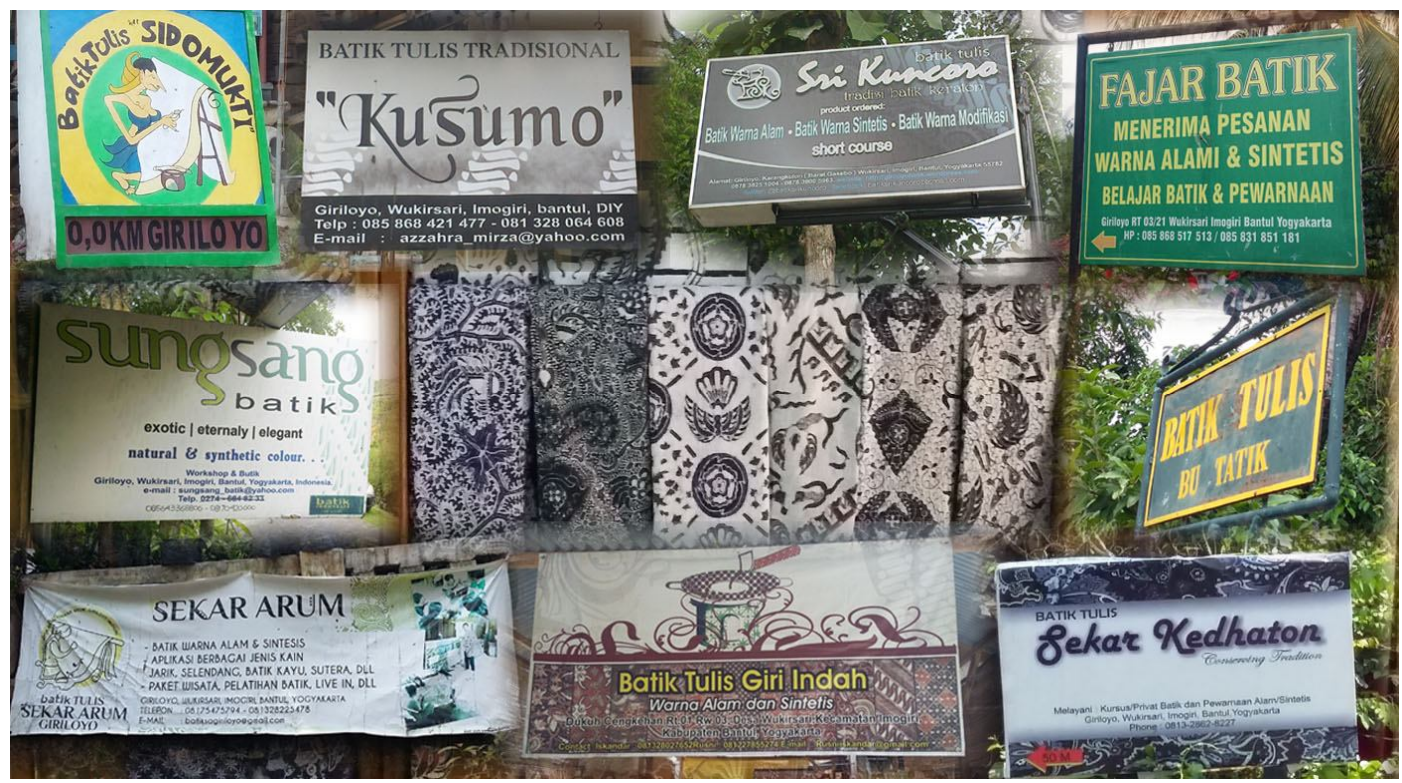

Gambar 3: Kelompok Batik tulis desa wisata giriloyo wukirsari 
Desi Susilawati, dkk. Penguatan Pemahaman Akuntansi Dan Perancangan...

Berdasarkan uraian diatas pengsbdi akan merancang aplikasi berbasis database Access '16 yang dapat membantu paguyuban dalam mengelola, memantau data penjualan, penyusunan laporan keuangan yang dapat disajikan tepat waktu sehingga kualitas laporan keuangan meningkat. Program ini diawali terlebih dahulu dengan penguatan pemahaman teknis proses akuntansi sehingga para pengelola dapat mengopersionalkan aplikasi tersebut.

\section{METODE PELAKSANAAN}

Pelaksanaan program ini
dilakukan melalui 3 tahap awal yaitu observasi dan diskusi lanjutan, tahap kedua yaitu pelatihan penguatan pemahaman teknis proses akuntansi dan perancangan aplikasi berbasis database dan tahap ketiga yaitu monitoring.

Data yang digunakan adalah data primer yang diperoleh dengan metode wawancara langsung dengan ketua paguyuban batik tulis Giriloyo. Metode observasi dilakukan dengan melakukan pengamatan langsung pada proses entry data yang masih menggunakan manual. Fakta yang terkumpul, disusun, dijelaskan dan dianalisa dengan menggunakan pendekatan deskriptif. Pendekatan yang digunakan adalah dskusi dengan tujuan untuk memperoleh informasi permalahan dan kebutuhan mitra. Pendekatan Transfer knowledge juga dilaksanakan yang bertujuan meningkatkan kemampuan dan pemahaman sumber daya manusia sehingga dapat menyusun laporan keuangan yang relevan dan tepat waktu.

Penguatan pemahaman proses akuntansi kepada para pengelola paguyuban Batik tulis Giriloyo meliputi 1) peningkatan pemahaman logika akuntansi, 2) pencatatan transaski. Untuk peningkatan pemahaman logika akuntansi, Pengabdi terlebih dahulu memberikan pelatihan logika dasar (debet-kredit) dan proses penjurnalan, logika posting ke buku besar dan penyusunan neraca saldo sebelum penyesuaian hingga neraca saldo setelah penyesuaian.

Pendekatan yang digunakan selain diskusi adalah problem solving yaitu lanngsung praktik berdasarkan transaksi yang ada dan tanya jawab unutk penyelesaian transaksi. Penguatan pemahaman didahului dengan pengenalan beberapa istilah-istilah dalam akuntansi. Selanjutnya menganilis transaksi dengan cara mencatat transasksi penjualan, transaksi pembeliaan persediaan barang dagangan dan mencatat seluruh biaya operasioanal. Selanjutnya mitra dan pengabdi mempraktikkan penyusunan laporan keuangan yang diawali dengan laporan rugi/laba, laporan arus kas, laporan perubahan ekuitas dan laporan posisi keuangan. Pengabdi juga memberikan penjelasan mengenai korelasi atau hubungan diantara keempat bentuk laporan keuangan tersebut. Dengan pelatihan ini diharapkan para pelaku bisnis selalu disiplin untuk melakukan pencatatan (penbukuan) untuk mengukur perkembangan usaha serta selalu berinovasi untuk menghadapi kondisi bisnis yang berfluktuatif. Pelatihan juga memaparkan bahwa pentingnya pembukuan keuangan walaupun sederhana bagi segala bentuk usaha.

Metode Monitoring dengan metode coaching, juga dilaksanakan dimana pengelola menunjukkan hasil pencatatan transaksi dan menyampaikan alur proses sehingga terbit laporan keuangan. Selain memberikan pelatihan, Pengabdi juga melakukan pemantauan untuk meninjau 
perkembangan hasil pelatihan dan pendampingan uji coba.

Pendampingan uji coba penggunaan aplikasi. Penjelasan sistem informasi keuangan agar mudah dipahami oleh mitra sekaligus mitra menginput data. Dengan langkah pelaksanaan berupa pendampingan penggunaan aplikasi karena masyarakat masih sangat minim pengetahuan tentang aplikasi. Pengabdi dapat melakukan perbaikan serta menyempurnakan fitur- fitur aplikasi sesuai kebutuhan mitra.

\section{HASIL DAN PEMBAHASAN}

\section{Aspek Penguatan Pemahaman Proses Akuntansi}

Berdasarkan hasil observasi \& diskusi dengan pengelola Paguyuban batik tulis Giriloyo diperoleh informasi, yaitu; pertama para pengelola belum sepenuhnya memahami proses/ alur pencatatan akuntans atau siklus transasksii sehingga akan mengalami kesulitan ketika mengimplementasikan aplikasi database yang akan kita rancang. Kedua, Para pengelola masih kurang bisa menafsirkan makna dari setiap transaksi yang terhubung dengan laporan keuangan dan yang terakhir para pengelola masih belum memahami fungsi menu dalam penyusunan laporan mutasi persediaan barang dagangan dan aporan penjualan. $\begin{array}{ccr}\text { Setelah melakukan survey } & \text { mada }\end{array}$ mengidentifikasi kebijakan manajemen dan akuntansi yang diterapkan di Paguyuban batik tulis Giriloyo. Pengabdi menyusun materi pelatihan. penguatan pemahaman proses akuntansi dan penyusunan laporan keuangan meliputi: Logika dasar dan Persamaan Akuntansi Dasar, Jenis - jenis laporan keuangan dan hubungan diantara laporan keuangan, Logika Penjurnalan, Logika dan pemahaman akun/rekening dan Buku Besar. Jurnal khusus dan Neraca saldo sebelum penyesuaian, jurnal penyesuaian dan neraca saldo setelah penyesuaian. Penjelasan bentuk - bentuk laporan keuangan:

a) Laporan Aliran Kas: yang berfungsi menjelaskan tentang jumlah penerimaan dan pengeluaran kas dalam suatu periode beserta sumbersumbernya.

b) Laporan Laba Rugi yang berfungsi memberikan informasi tentang aktivitas bisnis (usaha), misalnya pendapatan penjualan, biaya pembelian persediaan barang dagangan, baiay operasional lainnya, rugi atau laba (Keuntungan).

c) Laporan Perubahan Ekuitas yang berfungsi menggambarkan peningkatan atau penurunan modal/ ekuitas selama suatu periode tertentu.

d) Laporan Posisi Keuangan yang berfungsi menjelaskan nilai asset, liabilitas, dan ekuitas.

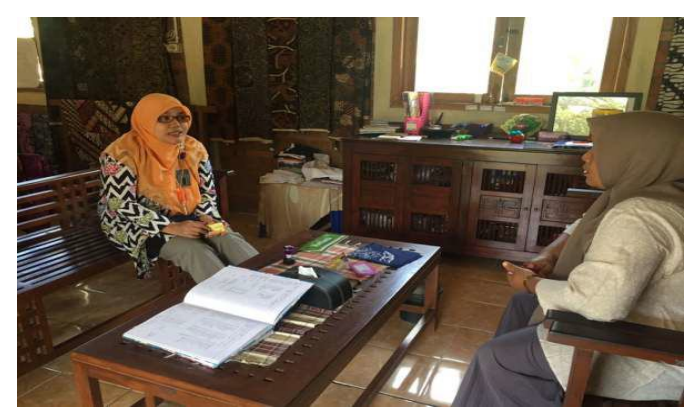

Gambar 4: Proses pelatihan teknis pemahaman proses akuntansi 
Desi Susilawati, dkk. Penguatan Pemahaman Akuntansi Dan Perancangan...

Setelah mengikuti kegiatan ini, pemahaman para pengelola paguyuban akan proses akuntansi seperti logika dasar (debet-kredit) dan proses penjurnalan, logika posting ke buku besar dan penyusunan neraca saldo sebelum penyesuaian hingga neraca saldo setelah penyesuaian hingga output laporan keuangan (laporan Aliran Kas, laporan rugi/laba. laporan posisi keuangan serta laporan perubahan Ekuitas) telah meningkat pemahamannya.

Tabel 1. Progress Peningkatan Pemahaman Proses Akuntansi bagi pengelola Paguyuban Batik Tulis Wukirsari

\begin{tabular}{|c|c|c|c|}
\hline \multirow[t]{2}{*}{ No } & \multirow[t]{2}{*}{ Materi } & \multicolumn{2}{|c|}{ Penguasaaan } \\
\hline & & Pre- test & Post- test \\
\hline 1 & $\begin{array}{l}\text { Logika dasar dan Persamaan Akuntansi } \\
\text { Dasar }\end{array}$ & Belum paham & paham \\
\hline 2 & $\begin{array}{l}\text { Jenis - jenis laporan keuangan dan } \\
\text { hubungan diantara laporan keuangan }\end{array}$ & Belum paham & paham \\
\hline 3 & Logika Penjurnalan & Kurang paham & paham \\
\hline 4 & $\begin{array}{l}\text { Logika dan pemahaman akun/rekening dan } \\
\text { Buku Besar }\end{array}$ & Kurang paham & paham \\
\hline 5 & Analissis transaksi & Kurang paham & paham \\
\hline 6 & Jurnal Khusus dan posting & Kurang paham & paham \\
\hline 7 & Neraca saldo dan Jurnal Penyesuaian & Kurang paham & paham \\
\hline 8 & Penyusunan Laporan Rugi Laba & Kurang paham & paham \\
\hline 9 & Penyusunan Laporan Aliran kas & Kurang paham & paham \\
\hline 10 & Penyusunan Laporan Ekuitas & Kurang paham & paham \\
\hline 11 & $\begin{array}{l}\text { Penyusunan Laporan Posisi Keuangan } \\
\text { (Neraca) }\end{array}$ & & \\
\hline
\end{tabular}

Setelah memahami karakteristik

Aspek Sistem Informasi Manajemen Keuangan

Pengembangan sistem informasi manajemen Batik Tulis Giriloyo ini adalah memperbaiki sistem keuangan dan sistem data yang belum terintegrasi dengan sistem perangkat lunak. Sehingga mereduksi dan menambah sistem serta analisis jika menggunakan perangkat lunak dan mencoba merevisi sistem data manual yang sudah ada.

Langkah _ Langkah pengembangan sistem informasi manajemen keuangan yang berbasis database Access diawali dengan pendekatan hasil analisa SWOT (Strength, Weakness, Opportunity, Threat), ditunjukkan dengan gambar 5. kualitas output laporan keuangan yang sesuai dengan kebutuhan mitra, langkah selanjutnya yang ditembuh adalah 1) Perancangan aplikasi berbasis database dan 2) Pengujian aplikasi dan pengolahan data analisis. Analisis hasil pengujian adalah salah satu eksperimen yang penting dalam pengembangan aplikasi database. Dengan menggunakan pengujian software sampai menginstall program dan menjalankannya. Dari data pengujian tersebut sistem akan dianalisis dan melakukan perbaikan-perbaikan yang dilakukan sebelum menggunakan software. 


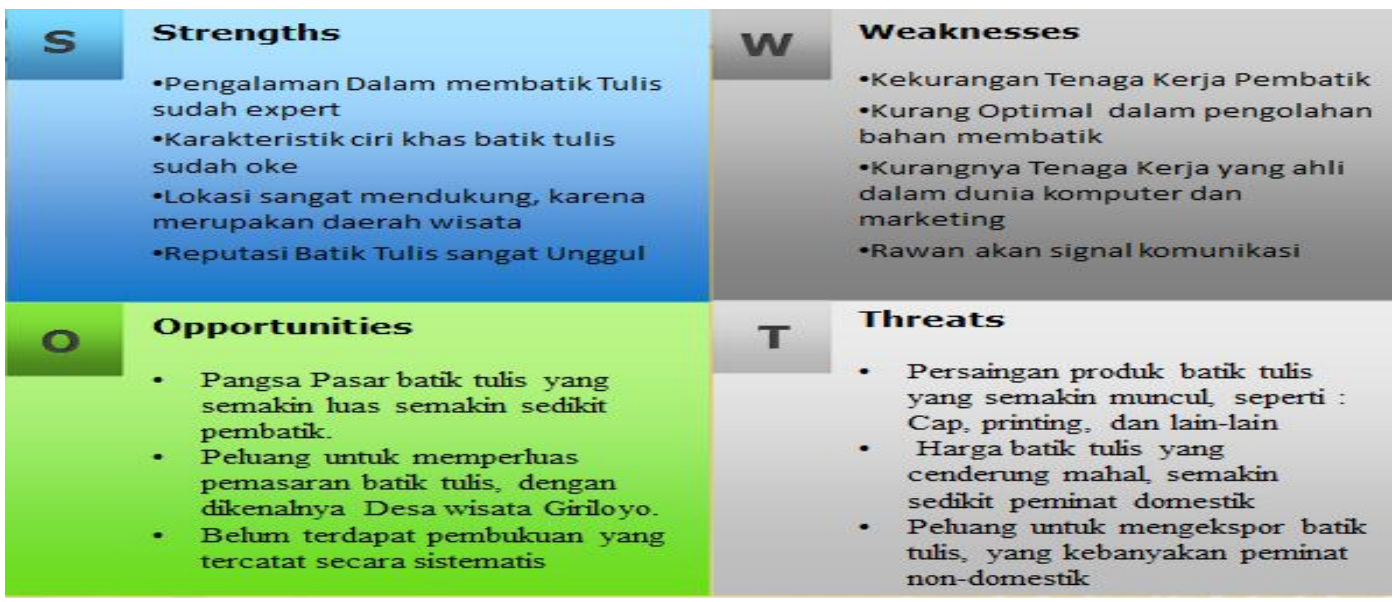

\section{Gambar 5: Analisis SWOT}

Setelah memahami karakteristik kualitas output laporan keuangan yang sesuai dengan kebutuhan mitra, langkah selanjutnya yang ditembuh adalah 1) Perancangan aplikasi berbasis database dan 2) Pengujian aplikasi dan pengolahan data analisis. Analisis hasil pengujian adalah salah satu eksperimen yang penting dalam pengembangan aplikasi database. Dengan menggunakan pengujian software sampai menginstall program dan menjalankannya. Dari data pengujian tersebut sistem akan dianalisis dan melakukan perbaikan-perbaikan yang dilakukan sebelum menggunakan software.

Sistem informasi manajemen keuangan yang berbasis teknologi, untuk mempermudah akses saat ingin membeli bahan baku, mengetahui stok, melakukan pemasaran, dll. Dengan aliran sistem informasi manajemen keuangan bisa dilihat diagram prosesnya.

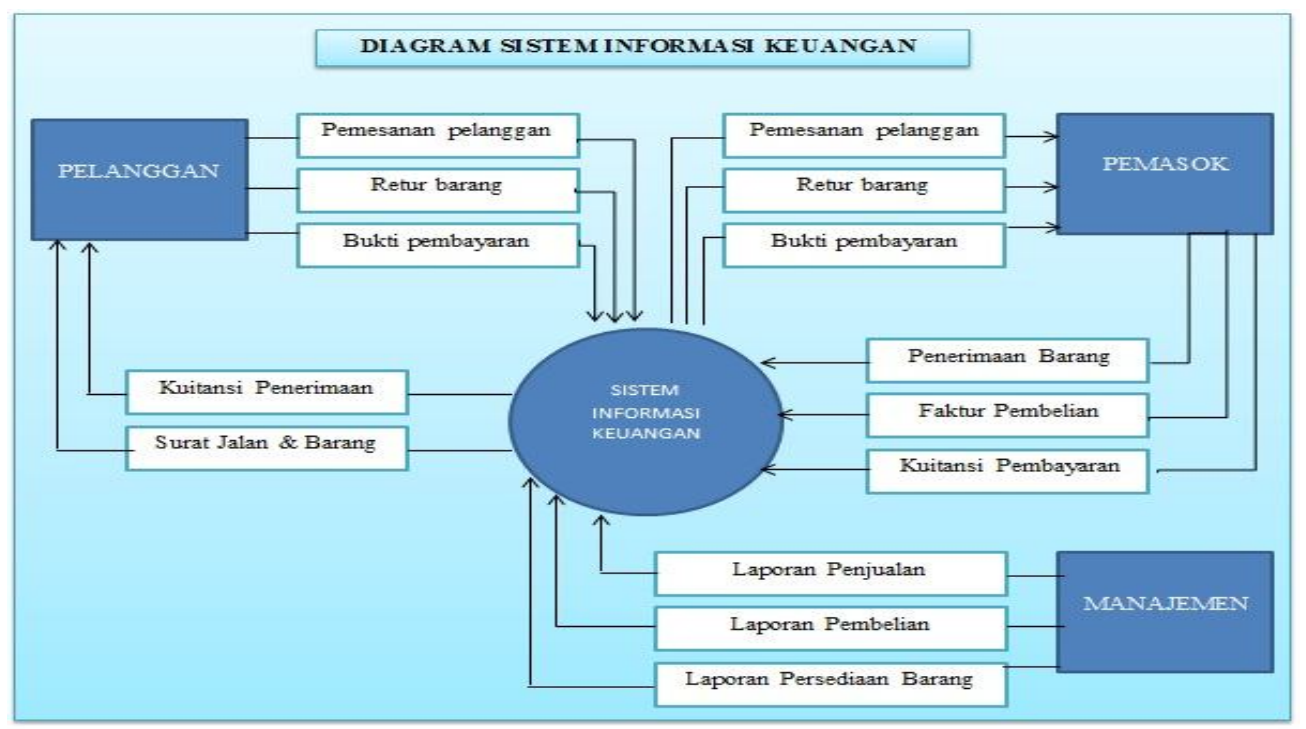

Gambar 6: Diagram proses sistem informasi keuangan 
Desi Susilawati, dkk. Penguatan Pemahaman Akuntansi Dan Perancangan...

Langkah - Langkah aplikasi dijalankan, dengan prosedur pada sistem informasi keuangan, adalah:

a) Pesan barang : pada sistem yang ini berlaku saat ada pemesanan maka di liat pada pembelian dengan melakukan pengecekan terlebih dahulu apakah masih tersedia di gudang atau sudah all of stock. Saat berhasil dicetak pemesanan yang kemudian langsung ditujukan kepada pembatik (Supplier).

b) Terima barang: pada sistem ini pembelian yang menerima barang berdasarkan barang yang dipesan, yang kemudian bagian pembelian akan mencetak bukti penerimaan barang sesuai dengan barang yang diterima. c) Retur pembelian: pada sistem ini adalah sistem tukar, dimana konfirmasi pembeli ada komplain, misal: produk cacat, tidak sesuai pesanan, rusak, dll. Maka pada sistem ini akan di cetak retur dengan cetak pembelian masih tersimpan.

d) Bayar tagihan / bayar hutang: sistem ini supplier melakukan pembelian tapi dengan sistem pembayaran hutang dan saat ingin menembus dengan menunjukkan bukti pembelian.

Pemodelan relationship atar data yang merupakan hasil rancangan fungsional sistem bisa dilihat di bawah ini:

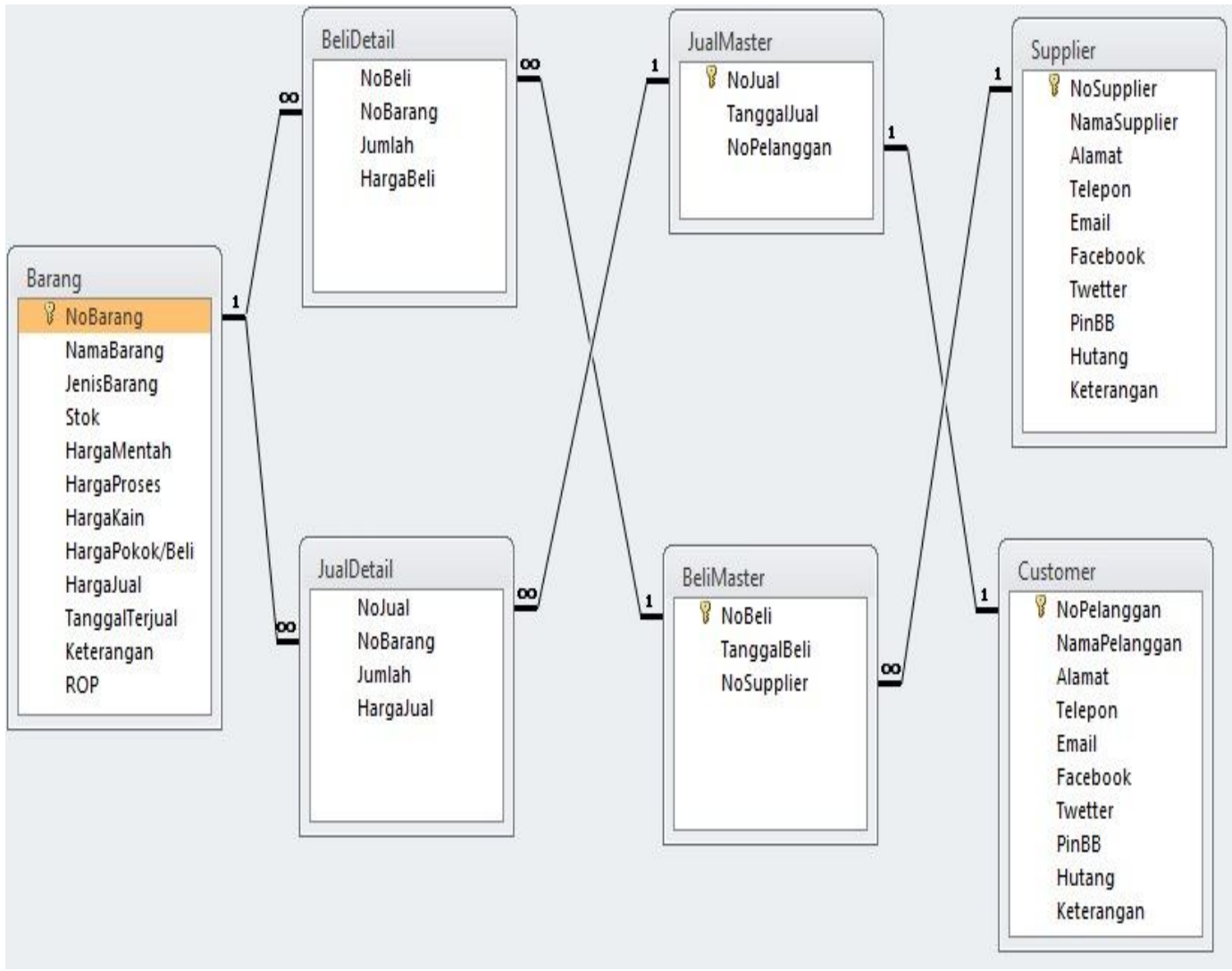

Gambar 7: Diagram entity - relationship 
Bagan tersebut menunjukkan bahwa identitas pemodelan bisa diidentifikasi dengan data dan

hubungan antar data, sehingga menghasilkan database seperti di bawah ini:

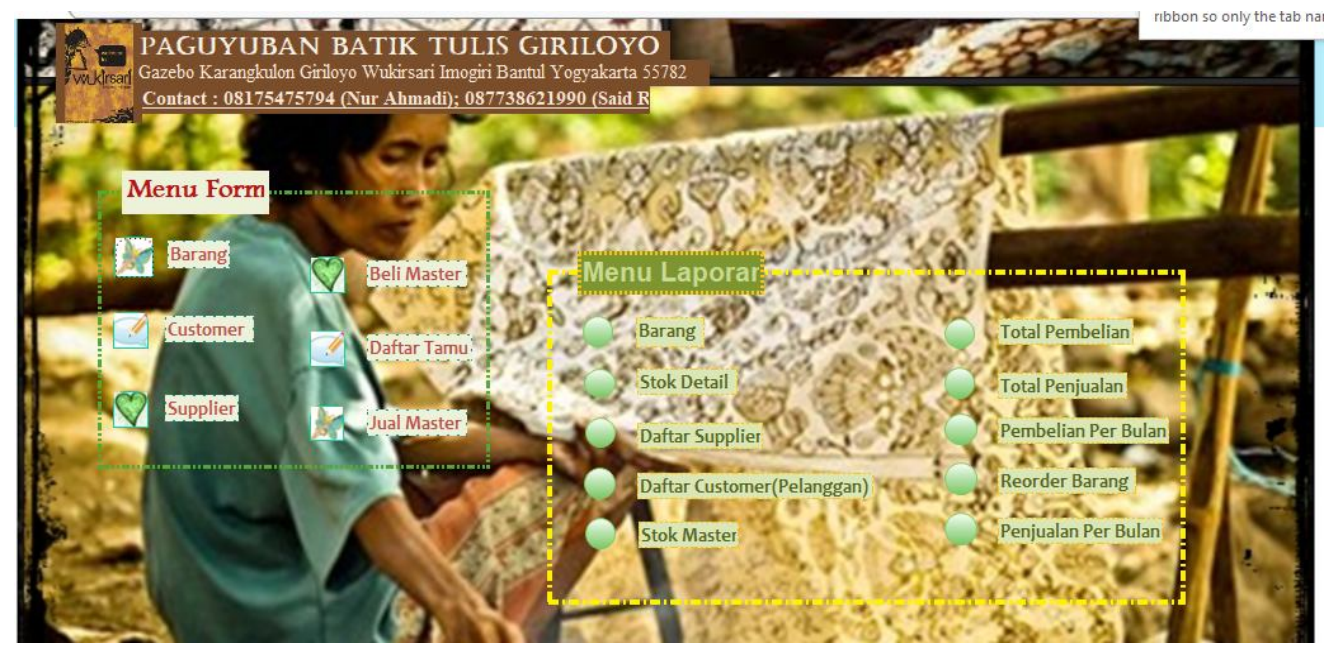

Gambar 8: Tampilan Database

Menu form terdiri dari 2 bagian, yaitu :

a) Menu form untuk pelanggan

Menu ini terdiri dari : Pelanggan sendiri, barang yang sudah terserap oleh pelanggan dan sangat disukai oleh pelanggan, dan supplier fungsinya untuk mengetahui barang yang habis stock.

b) Menu laporan untuk rekap harian, mingguan dan bulanan
Menu ini terdiri dari : laporan harian oleh paguyuban yang bisa dilihat oleh beberapa kelompok batik. Bisa di lihat langsung saat mingguan maupun bulanan.

Beberapa form - form barang, pembelian, dan Laporan penjualan setelah menggunakan aplikasi,dapat di lihat pada gambar di bawah ini, yaitu :

\begin{tabular}{|c|c|c|c|c|c|}
\hline \multicolumn{6}{|c|}{ Laporan Daftar Batik } \\
\hline Nama Barang & ID Barang & Tipe Barang & HargaPokok/Beli & HargaJual & Stok \\
\hline ANGGUR & Bo17 & SB & $130.000,00$ & $350.000,00$ & 2,00 \\
\hline BURUNG ITIK MAWAR & Bo14 & SB & $125.000,00$ & $350.000,00$ & $2, \infty 0$ \\
\hline BURUNG ITIK MAWAR & Bo15 & SB & $100.000,00$ & $330.000,00$ & 2,00 \\
\hline GEGAT RINING & Bo31 & ws & $290.000,00$ & $600.000,00$ & 2,00 \\
\hline KAWUNG CEREK & Bo13 & ws & $125.000,00$ & $380.000,00$ & 2,00 \\
\hline KAWUNG CEREK & Bo16 & SB & $100.000,00$ & $330.000,00$ & 2,00 \\
\hline KAWUNG CEREK & Bo12 & ws & $255.000,00$ & $450.000,00$ & 2,00 \\
\hline KEYONG & Возо & w & $200.000,00$ & $450.000,00$ & 2,00 \\
\hline KLUBUK RINING & Booz & ws & $260.000,00$ & $500.000,00$ & 2,00 \\
\hline KUNIR PISO & Boo5 & w & $195.000,00$ & $500.000,00$ & 2,00 \\
\hline LEREK KEMBANG API & Boog & w & $200.000,00$ & $375.000,00$ & 2,00 \\
\hline LEREK KEMBANG API & Boo8 & w & $205.000,00$ & $505.000,00$ & 2,00 \\
\hline MERAK & Bo25 & SHR & $230.000,00$ & 610.000,00 & 2,00 \\
\hline
\end{tabular}

Gambar 9: Tampilan Laporan penjualan 
Desi Susilawati, dkk. Penguatan Pemahaman Akuntansi Dan Perancangan...

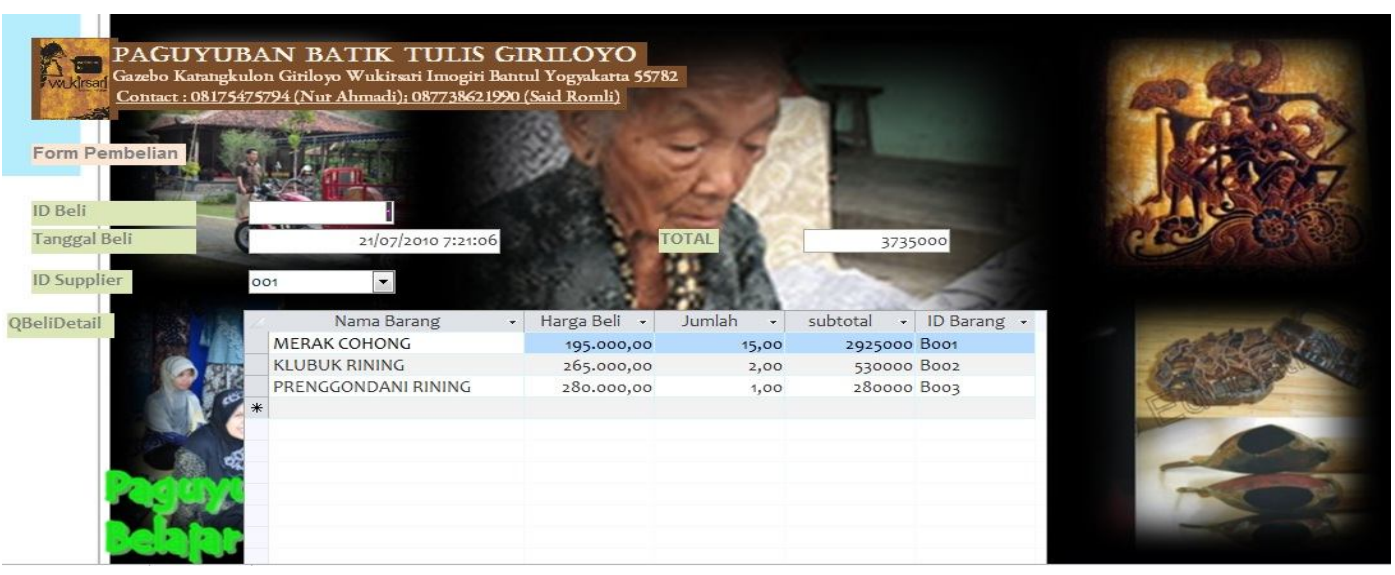

Gambar 10: Tampilan saat pelanggan membeli produk

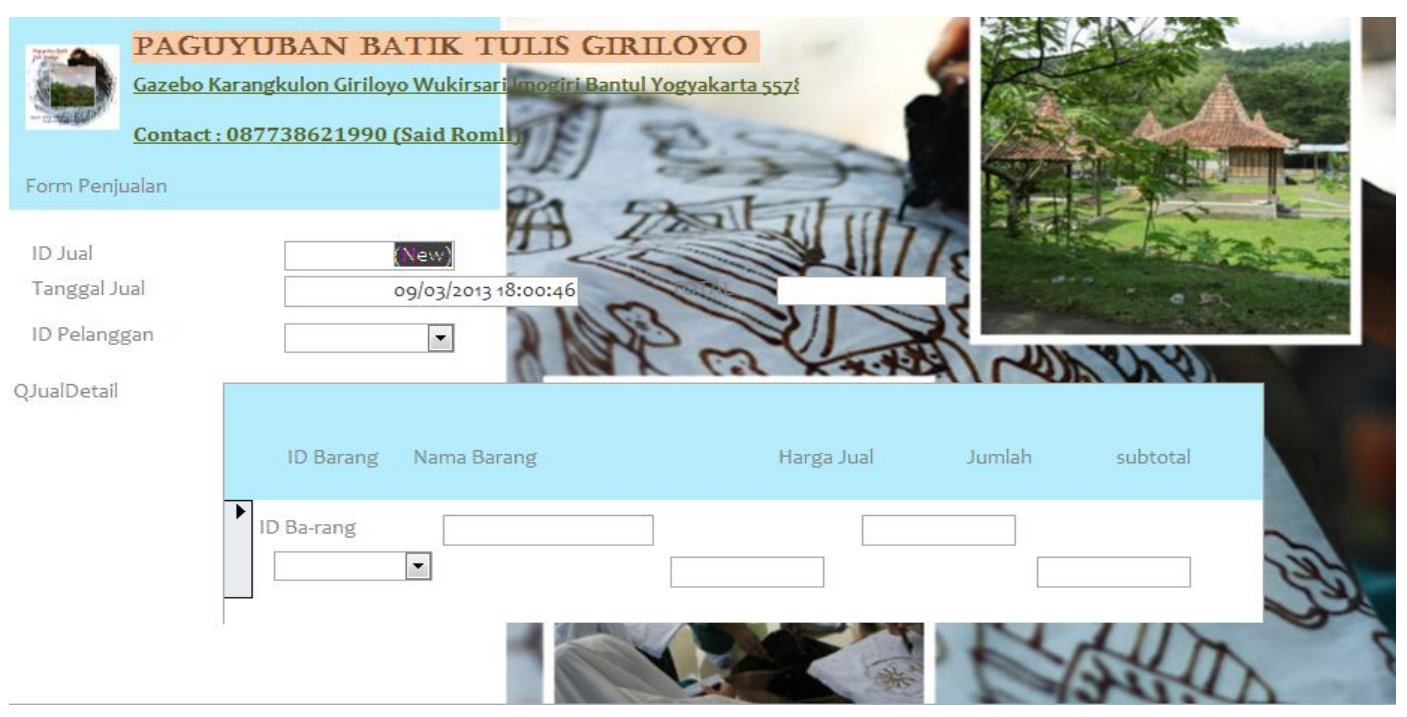

Gambar 11: Tampilan saat kelompok batik menjual produk

Penjelasan singkat diatas merupakan sistem informasi keuangan yang cukup mudah dipahami oleh mitra. Dengan langkah pelaksanaan berupa pendampingan dan pelatihan penggunaan aplikasi karena masyarakat masih sangat minim pengetahuan tentang aplikasi.

Selain dengan analisis SWOT, Pengabdi juga membagikan kuesioner kepada pembatik di kelompok batik tersebut.untuk mengukur apakah penggunaan aplikasi tersebut mudah. Untuk mengukur efektivitas penggunaan aplikasi, Pengabdi mendistribusikan kuesioner kepada 50 responden untuk menanyakan apakah penggunaan aplikasi mampu menghasilkan output berupa laporan penjualan dan laporan mutasi persedian tersaji tepat waktu. Hasil yang didapat dari adalah $74 \%$ dari 37 responden menyatakan bahwa penggunaan aplikasi database Acsess memudahkan pengelola untuk menyususn laporan keungan dan adapat tersaji tepat waktu. Dengan persentase tersebut dapat dilihat bahwa paguyuban batik tulis memerlukan sistem informasi manajemen untuk pengelolaan. 


\section{SIMPULAN}

Hasil pembahasan dapat ditarik kesimpulan, yaitu : Pemahaman teknis proses akuntansi bagi para pengelola paguyuban semakin meningkat. Paguyuban batik tulis Wukirsari sangat memerlukan sistem informasi yang terintegrasi dengan aplikasi berbasis database, Feedback dari Kuisioner yang didapat setelah aplikasi ini diterapkan pada pengguna, adalah sebagian besar pengguna yaitu sebanyak $74 \%$ menyatakan implementasi aplikasi database ini mudah. Database yang sederhana dapat digunakan untuk entry data, update data, history data, restock barang sampai reorder barang. Sistem informasi dengan model aplikasi berbasis database sangat diperlukan dalam pengembangan kelompok batik tulis wukirsari.

Setelah mendapatkan pelatihan maka pemahaman proses akuntansi para Pengelola Paguyuban batik tulis Giriloyo semakin meningkat. Setelah peng implementasian sistem informasi manajemen keuangan berbasis database menguunakan Access, pengelola paguyuban dapat menyususn laporan keuangan, seperti laporan penjualan, laporan mutasi persediaan barang dagangan tepat waktu sehingga meningkatkan kualitas laporan keuangan.

\section{UCAPAN TERIMA KASIH}

Pengembangan sistem keuangan dan penguatan pengetahuan teknis akuntansi ini dapat terlaksana tidak terlepas dari partisipasi beberapa pihak, sehingga pengabdi mengucapkan banyak terima kasih : Lembaga Pendidikan, Penelitian dan Pengabdian Pada Masyarakat (LP3M) Universitas Muhammadiyah Yogyakarta. Paguyuban Batik Tulis Giriloyo
Wukirsari Imogiri Bantul. Kelompok Sidomukti, Mekar sari, Sri Kuncoro, Sekar Arum, Giri Indah dan kelompok lainnya. Bapak Nur Ahmadi selaku ketua paguyuban.

\section{DAFTAR PUSTAKA}

Abdul kadir \& Terra Ch. Triwahyuni. (2003). Pengenalan Teknologi Informasi. Yogyakarta: Andi Offset.

Jogiyanto, H. M. (2005). Analisis dan Design: Sistem Informasi Pendekatan Terstruktur Teori dan Praktik Aplikasi Bisnis. Yogyakarta: Penerbit Andi Offset.

Pratikno, Andri. Waluyo dan Putra Richardo. (2011). Super Access 5 langkah mudah membuat aplikasi dagang. Jakarta: PT.Elek Media Komputer.

Rachmawati, Putri. (2013). Perancangan Sistem Informasi Manajemen Keuangan Usaha Kecil Menengah Berbasis Access 2010. UGM Yogyakarta.

Widjajanto, Nugroho. (2011). Sistem Informasi Akuntansi . Jakarta : Erlangga. 